\title{
Fixed Bed Adsorption and Modelling for Desulphurization of Diesel Using Coconut Shell Activated Carbon
}

\author{
Pratibha R.Gawande ${ }^{1}$, Dr.Jayant P.Kaware ${ }^{2}$ \\ ${ }^{1}$ Faculty of department of chemical engineering, Datta Meghe college of Engineering, Airoli, Navi Mumbai, \\ Maharashtra, India. \\ ${ }^{2}$ Principal, Rajarshi Shahu College of Engineering,Buldhana, Maharashtra, India
}

*Corresponding Author: Pratibha R.Gawande, Faculty of department of chemical engineering, Datta Meghe college of Engineering, Airoli, Navi Mumbai, Maharashtra, India.

\begin{abstract}
Removal of sulphur from diesel was carried out by using by using coconut shell activated carbons. Fixed bed adsorption experiments was performed for determination of break through curve at room temperature. Experiments were carried out with different flow rates .initial concentration, and bed heights. The experiments of three different bed height, $100 \mathrm{~mm}, 200 \mathrm{~mm}$, and $300 \mathrm{~mm}$ with three different flowrate 1.6 $\mathrm{ml} / \mathrm{min}, 3.6 \mathrm{ml} / \mathrm{min}$ and $5.6 \mathrm{ml} / \mathrm{min}$.Also experiments with three different sulphur concentration334.5 ppm, 167.25ppm and $86.625 \mathrm{ppm}$. Adsorption of sulphur from diesel is presented in the form of breakthrough curves (i.e. C/Co Vs t) In almost all the experiments, the exit conc.at 0 time was more than 30\%.(C/CO).so breakthrough point as such can not be found. The breakthrough curve was different than typically observed in packed bed experiment so exaution time was considered and analysed for variation in various parameter. The performance of fixed bed in the form of breakthrough curves were obtained and tested using different kinetic models like Thomas, Adam-Bohart, Yoon-Nelson.Adsorption capacity $(\mathrm{mg} / \mathrm{g})$ was found from the models. The constants obtained from the models can be utilized for designing the industrial scale fixed bed. The performance of the regenerated sorbent bed was tested and found similar to that of the fresh adsorbent bed indicating the usefulness of the developed regeneration process.
\end{abstract}

\section{INTRODUCTION}

Dat $\mathrm{T}$ et.al. adsorptive desulfurization of jp-8 fuel using 1- and 2-D mesoporous silica as supporting materials for silver ions, with silver loading up to $33 \mathrm{wt} . \%$. Packed-bed adsorption experiments were carried out in a column reactor at room temperature, using a liquid pump to pump the JP-8 fuel through the reactor for higher desulfurization. Authors were observed that the initial performance of sulfur removal from JP- 8 fuel is nearly $100 \%$ but gradually drops down and plateaus at around $68 \%-$ $70 \%$ sulfur removal before dropping below $50 \%$ after $40 \mathrm{ml}$. of JP-8 fuel processed[1].

Penelope Baltzopoulou et.al. diesel fuel desulfurization via adsorption with the aid of activated carbon laboratory and pilot-scale studies. Investigators were carried out both laboratory and pilot scale experiments performed in dedicated fixed bed setups. Under laboratory scale conditions, maximum sulfur removal measured was exceeded $90 \%$. The continuous tests were performed in a vertical fixed bed adsorption reactor and were employed for the generation of dynamic total sulfur breakthrough curves[2].

Alain Favre Re et.al were studied deep desulfurization of diesel feedstock by selective adsorption of refractory sulfur compounds. Investigators were studied adsorptive desulfurization using straight-run gas oil with various sulfur contents like 390 and $60 \mathrm{ppm}$ of sulphur. They were carried out column breakthrough experiments were carried out in jacketed glass column which was packed with resin avoid entrapped air bubbles within the column at $50{ }^{\circ} \mathrm{C}$. Authors were studied fixed bed adsorption studies on SRGO with different sulfur concentrations which was effective under very mild process conditions [3].

Huang Tang et.al. were investigated improvement in diesel desulfurization capacity by equilibrium isotherms analysis. Investigators were carried out adsorption experiments with both model oils and diesel fuels on fixed bed using mesoporous aluminosilicates as adsorbent. Adsorbents were loaded on 
to the fixed bed and activated at $400{ }^{\circ} \mathrm{C}$ in $\mathrm{N} 2$ atmosphere for $2 \mathrm{~h}$ before adsorption process and flow rate was $12 \mathrm{~mL} / \mathrm{h}$.A. Authors were concluded that complexation adsorbents were more efficient to remove sulfur compounds at higher temperature[4].

Wei wei Li et.al. were investigated solvent desulfurization regeneration process and analysis of activated carbon for low sulfur real diesel. Investigators were carried out dynamic adsorption experiments by flowing diesel through a fixed bed at room temperature to determine the adsorption capacity of activated carbon. The adsorption experiment was carried out with a LHSV of $5.97 \mathrm{~h}$. The total sulfur content varies of real diesel in the outlet of fixed bed with different time was measured. Authors were observed that The sulphur content in diesel was reduced to less than $10 \mathrm{ppm}$ from an initial sulphur content of $34.83 \mathrm{ppm}[5]$.

Mykola Seredych et.al were studied Textural and chemical factors affecting adsorption capacity of activated carbon in highly efficient desulfurization of diesel fuel. Authors were carried out adsorption process at ambient temperature and pressure. They were investigated two synthetic, polymer-derived carbons, and two commercial carbons as adsorbents of dibenzothiophene and 4,6dimethyldibenzothiophene from simulated diesel having sulphur cotent $20 \mathrm{ppm}$. Model fuel was passed into the column with adsorbent from the top by peristaltic pump with a flow rate of $8.3 \mathrm{ml} / \mathrm{h}$. Authors were observed that amount adsorbed was mainly governed by the volume of micropores, where dispersive interactions were predominant[6].

Vinay M. Bhandari et.al were studied desulfurization of diesel using ion exchanged zeolites. Studies were carried out on a model diesel comprising all the major refractory sulfur compounds such as benzothiophene, dibenzothiophene and 4,6-dimethyl dibenzothiophene and also on commercial diesel. All dynamic adsorption experiments or breakthrough tests were carried out in quartz column using upflow conditions in all the experiments. Authors were carried out experiments with both solvent wash using sulfur-free $n$-octane and without solvent wash.Authors were observed that various ion exchanged zeolite adsorbents was confirmed high capacity for sulfur removal [7].Jie Bu et.al were investigated desulfurization of diesel fuels by selective adsorption on activated carbons competitive adsorption of polycyclic aromatic sulfur hetero cycles and polycyclic aromatic hydrocarbons. Both batch and fixed bed continuous adsorption experiments were carried out of real and model diesel fuels containing aromatics and sulfur compounds over several activated carbons. In order to study the adsorption performance of activated carbons, four experiments were carried out using MD in a fixed bed column packed with $\mathrm{AC} 7$ at $25{ }^{\circ} \mathrm{C}$ and employing a liquid hourly space velocity of $0.5 \mathrm{~h}-1$. Authors were concluded that adsorption capacity of PASHs decreases significantly in the presence of PAHs as result of the adsorption competition due to similar structure, molecular diameter and adsorption mechanisms[8].

Soumen Dasguptaet.al were investigated adsorptive desulfurization of diesel by regenerable nickel based adsorbents. Investigators were investigated NiY and NiMCM 41 for adsorptive sulphur removal from refinery diesel. Adsorption breakthrough experiments were carried out in an automated adsorber system. Authors were concluded that NiY and NiMCM-41 could reduce the sulphur level from 450 ppm in an actual refinery diesel to less than $50 \mathrm{ppm}[9]$. Anne Kerolaine O. Rodrigues et.al were studied Pd loaded mesoporous silica as a robust adsorbent in adsorption/desorption desulfurization cycles. Investigators were carried out fixed bed adsorption/breakthrough experiments in a fixed bed setup by introducing benzothiophene solutions. The adsorption column studies using SBA-15 and $\mathrm{PdCl}_{2} / \mathrm{SBA}-15$ as packing were carried out at $25{ }^{\circ} \mathrm{C}$ and with flow rates of 0.50 and $0.35 \mathrm{~mL} / \mathrm{min}$. Authors were investigated that PdCl2/SBA-15 had superior sulfur adsorption capacity, as compared to the metal halide alone and the silica support. It was also observed that the adsorbent could be nearly $100 \%$ regenerated, upon successive adsorption/desorption cycles[10].

Marko Muzic et.al were investigated the removal of organic sulfur compounds from diesel fuel by activated carbon was investigated in a fixed bed column. The experiments were conducted to study the effects of process parameters such as flow rate, bed depth and temperature. They were developed mathematical model of the fixed bed adsorber. Fixed bed adsorptive desulfurization was carried out by simulation of an industrial adsorption column. Investigators were achieved sulfur content of less then $0.7 \mathrm{mg} / \mathrm{kg}$. for the lowest flow rate of $1 \mathrm{~mL} / \mathrm{min}[11]$. Marko Muzic et.al were studied kinetic and statistical studies of adsorptive desulfurization of diesel fuel on commercial activated carbons. Adsorptive desulfurization experiments were carried out using a semiautomatic laboratory apparatus. 
Investigators were studied statistical process two-level one-half fractional factorial experimental design with five process parameters. Experiments were carried out to determine the sulfur adsorption dependency on time, were used to perform kinetic characterization and to screen the best performing activated carbon[12].

M. Muzic et.al. desulfurization of diesel fuel in a fixed bed adsorption column experimental study and simulation. Investigators were investigated desulfurization of diesel in a fixed bed adsorption column using activated carbon as an adsorbent. The experiments were carried out at different feed flow rates, bed depths, and temperatures, and each experiment resulted in at least one sample containing less than $10 \mathrm{mg} / \mathrm{kg}$ of sulfur. The adsorptive desulfurization experiments were carried out in a fixed bed adsorption column were used to investigate the influence of feed flow, working temperature, and bed depth on output sulfur concentration and breakthrough time[13]. Authors were carried out desulphurization experiments using p-complexation based sorbents for diesel, gasoline, and jet fuels. They were investigated that the best sorbent, $\mathrm{Cu}(\mathrm{I})-\mathrm{Y}(\mathrm{VPIE})$, has breakthrough adsorption capacities of 0.395 and $0.278 \mathrm{mmol} \mathrm{S} / \mathrm{g}$ of sorbent for commercial jetfuel (364.1 ppmw S) and diesel (297.2 ppmw S), respectively. Based on fixed-bed adsorption data, it was found that the sorbent capacities for total sulfur removal decrease[14].

\section{Diesel AND ACTIVATED CARbON}

\subsection{Diesel Sample}

Before processing for desulfurization, diesel oil was characterized Various physicochemical properties like kinematic viscosity, density, ash contents, flash point and Cetane Index of the diesel oil was studied and shown in table no 2.1.

Table2.1. Characterization of Diesel sample

\begin{tabular}{|c|c|c|}
\hline Properties & Diesel sample & Testing method \\
\hline KinematicViscosity $(\mathrm{cSt}) \mathrm{at} 40^{\circ} \mathrm{c}$ & 2.320 & ISO 3104 \\
\hline Density $(\mathrm{g} / \mathrm{ml}) \mathrm{at} 15^{\circ} \mathrm{C}$ & 0.8273 & ISO 12185 \\
\hline Ash Content $\% \mathrm{wt}$ & 0.01 & ISO 6245 \\
\hline Flash Point $\left({ }^{\circ} \mathrm{C}\right)$ & 36.5 & ISO 2719 \\
\hline Cetane Index & 53.0 & ISO 4264 \\
\hline Sulfur content, ppm & 334.5 & ASTM D5453-2012 \\
\hline
\end{tabular}

\subsection{Coconut Shell Activated Carbon}

Adsorbent characterization including surface analysis was done for the best performing sorbent coconut shell activated carbon in order to better understand the mechanism and properties that lead to the improved adsorption performance. Coconut shell activated carbon was prepared and characterized various properties like. Ph, Moisture Content, Ash content, Volatile matter content, Iodine number, Bet surface area, Bulk Density Resulting estimated properties values are given in tableno 2.2.

Table2.2. Characterization of coconut shell activated carbon

\begin{tabular}{|c|c|c|}
\hline Sr No & Properties & Value \\
\hline i & P.H & 6.9 \\
\hline ii & \%Moisture Content & 0.5 \\
\hline iii & \%Ash content & 1.88 \\
\hline iv & Volatile matter content & 18.86 \\
\hline v & Iodine number & $942 \mathrm{mg} / \mathrm{g}$ \\
\hline vi & Bet surface area & $435.1 \mathrm{~m}^{2} / \mathrm{gm}$ \\
\hline vii & Bulk Density & $0.590 \mathrm{~g} / \mathrm{cc}$ \\
\hline
\end{tabular}

\section{PACKed Bed EXPERIMENTS FOR SUlPHUR REMOVAL}

Fixed bed adsorption experiments was performed for determination of break through curve at room temperature for coconut shell activated carbons of selected size.All adsorption/breakthrough experiments were performed in vertical column equipped with a supporting glass fits. Initially the adsorbents was loaded inside the adsober. The adsorbent was packed in a glass column having a bed dimension of $4.5 \mathrm{~cm}$ i.d. and $300 \mathrm{~mm}$ length. Experimental run was conducted by upflow contactor.The flow rate was adjusted by using needle valve. At the bottom end there is a wire mesh filter attached. Adsorbent was filled Above the 1 inch layer of sand. The tanks was filled with diesel 
sample and outlet sample was collected at bottom. Experiments were carried out with different flow rates .initial concentration, and bed heights.

\subsection{Breakthrough Curve}

Breakthrough curve represents the evaluation of the solution concentration in function of adsorption parameter like contact between liquid and solid phase solvent concentration and temperature. Breakthrough curves described behavior of fixed bed adsorption columns and the break through point is reached when outlet concentration begins to rise rapidly. The breakthrough curve normally takes an $\mathrm{S}$-shape. The steepness of the breakthrough curve determines the extent to which the capacity of an adsorbent bed can be utilized. Effect of various parameters like flowrate, initial concentration and bed height on breakthrough curve was studied.

\subsection{Effect of Feed Flow Rate}

The desulphurization performance of adsorbent strongly depends on the feed flow of diesel. The effect of feed flow rate on the adsorption of sulphur was investigated by varying the feed flow from 1.6 $\mathrm{ml} / \mathrm{min}, 3.6 \mathrm{ml} / \mathrm{min}$ and $5.6 \mathrm{ml} / \mathrm{min}$. with constant adsorbent bed height at constant feed concentration. It was found that as flow rate increases from $1.6 \mathrm{ml} / \mathrm{min}$ to $5.6 \mathrm{ml} / \mathrm{min}$. adsorptive capacity decreases significantly. The desulphurization performance of adsorbent strongly depends on the feed flow of diesel. Breakthrough curves obtained at different feed flow rates of diesel are shown in fig 3.2.1.fig 3.2.2. and fig 3.2.3.

Breakthrough occurred faster for increasing flow rates as for high feed flow rate, the adsorbate phase did not have enough time to be in contact with adsorbent particles and resulted in lower removal of sulphur. It was observed that lowering of feed flow was causing the lowering of initial values of output sulfur concentration and the extension of breakthrough time. Adsorptive desulphurization experiments were carried out at different flow rate. $1.6 \mathrm{ml} / \mathrm{min}, 3.6 \mathrm{ml} / \mathrm{min}, 5.6 \mathrm{ml} / \mathrm{min}$. with constant adsorbent bed height and sulphur concentration. It was found that all flow rates $1.6 \mathrm{ml} / \mathrm{min}$ the exhaustion time was 720,750 and 720 minutes for bed height $100 \mathrm{~mm} 200 \mathrm{~mm}$ and $300 \mathrm{~mm}$ respectively. At flowrate 3.6 $\mathrm{ml} / \mathrm{min}$ for bed height $100 \mathrm{~mm} 200 \mathrm{~mm}$ and $300 \mathrm{~mm}$, exhaustion time was $540 \mathrm{~min} 570 \mathrm{~min}$ respectively. The exhaustion time was $720 \mathrm{~min}$ for bed height $100 \mathrm{~mm}$ and $300 \mathrm{~mm}$.and $750 \mathrm{~min}$ for $200 \mathrm{~mm}$ bed height.

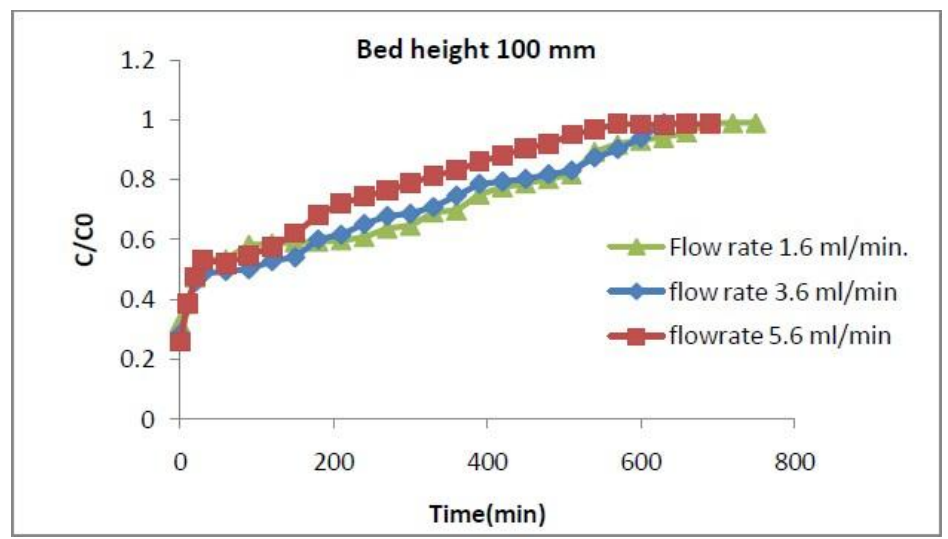

Fig.3.2.1. Effect of Flow rate on Break through Curve (Bed Height:100 mm)

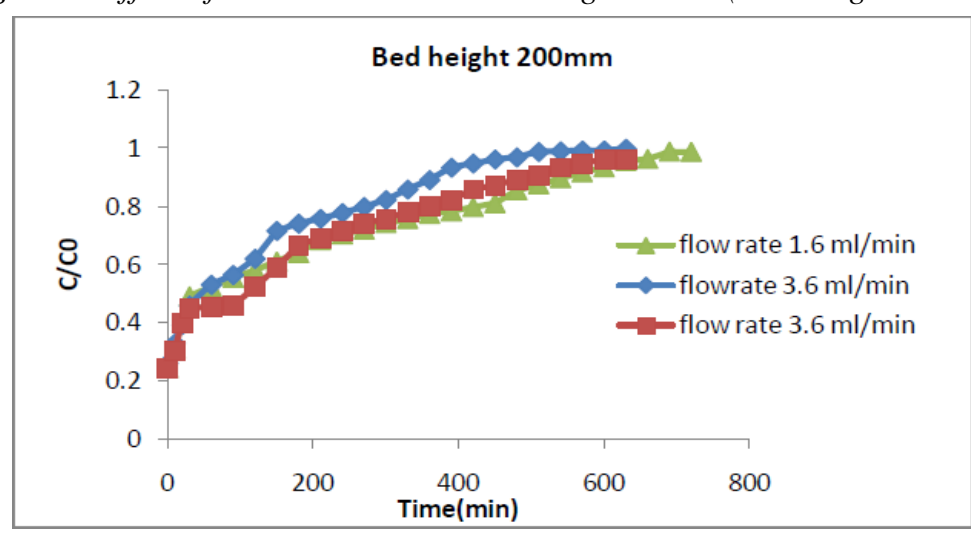

Fig.3.2.2 Effect of Flow rate on Break through Curve (Bed Height:200 mm) 


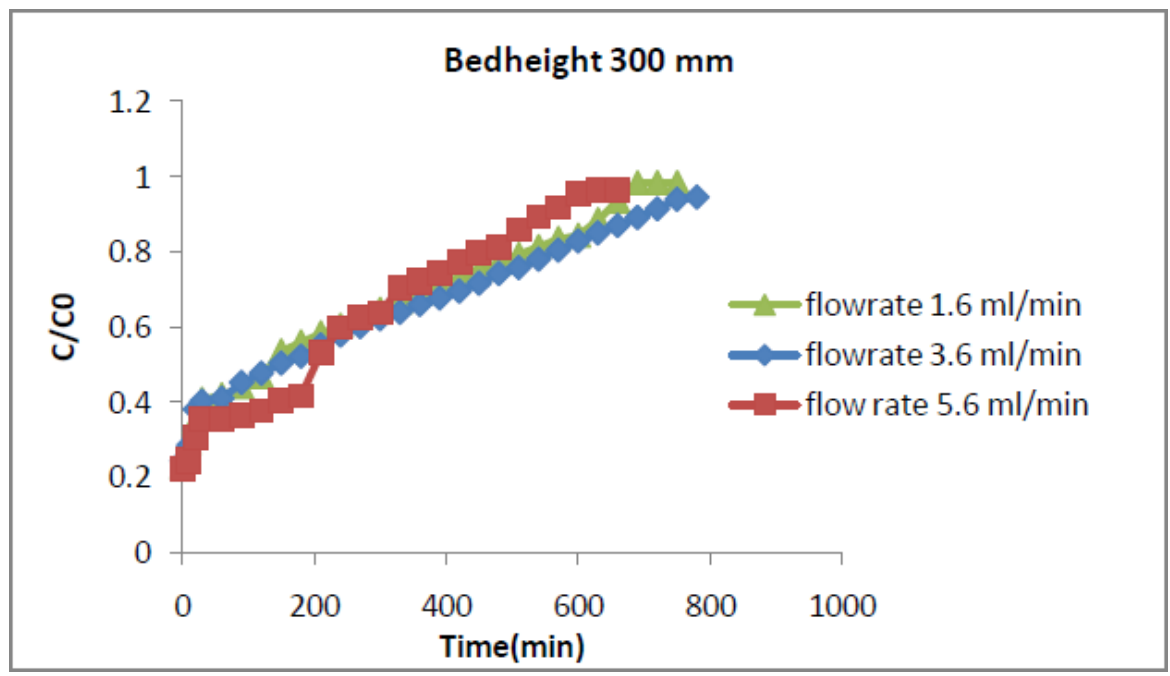

Fig.3.2.3. Effect of Flow rate on Break through Curve (Bed Height:300 mm)

\subsection{Effect of Bed Height}

For study the effect of bed height, keeping the same volume of adsorbent, the height of the packed bed was varied. To investigate the effect of the packed bed dimensions on the desulfurization capacity of the adsorbent, height of the packed bed were chosen and filled with selected adsorbent particles. Sulphur adsorption by coconut shell activated carbon in fixed bed column mainly depends upon the height of adsorbent bed in the column. The experiments was carried out at three different bed heights namely $100 \mathrm{~mm}, 200 \mathrm{~mm}$, and $300 \mathrm{~mm}$ keeping other parameters like conc. feed flow rate constant. To investigate the effect of the packed bed dimensions on the desulfurization capacity of the adsorbent, height of the packed bed were chosen and filled with selected adsorbent particles. The breakthrough curves for sulphur removal from diesel at different bed heights representing adsorbent mass loadings are shown in fig 3.3.1fig 3.3.2 and fig 3.3.3. Exhaustion time was seen increasing with increase in adsorbent bed height, which may be due to the availability of more time for contact between adsorbate and adsorbent.

For all the cases, the exhaustion time increases with bed height. For the bed height of $100 \mathrm{~mm}$, exhaustion time was 750,660 and 690 minutes respectively. The corresponding exhaustion time was 720 , at flowrate $1.6 \mathrm{ml} / \mathrm{min}$ and $630 \mathrm{~min}$ for $3.6 \mathrm{ml} / \mathrm{min}$ and $5.6 \mathrm{ml} / \mathrm{min}$ respectively for bed height 200 $\mathrm{mm}$.It was found that increase in bed height leads to decrease in the output sulfur concentration.200 $\mathrm{mm}$ bed height gives better results for flow rate $5.6 \mathrm{ml} / \mathrm{min}$ with sulphur removal $77.93 \%$.Maximum sulphur removal for $200 \mathrm{~mm}$ and $300 \mathrm{~mm}$ bed was found $74.11 \%$ and $75.68 \%$ respectively for flow rate $5.6 \mathrm{ml} / \mathrm{min}$.

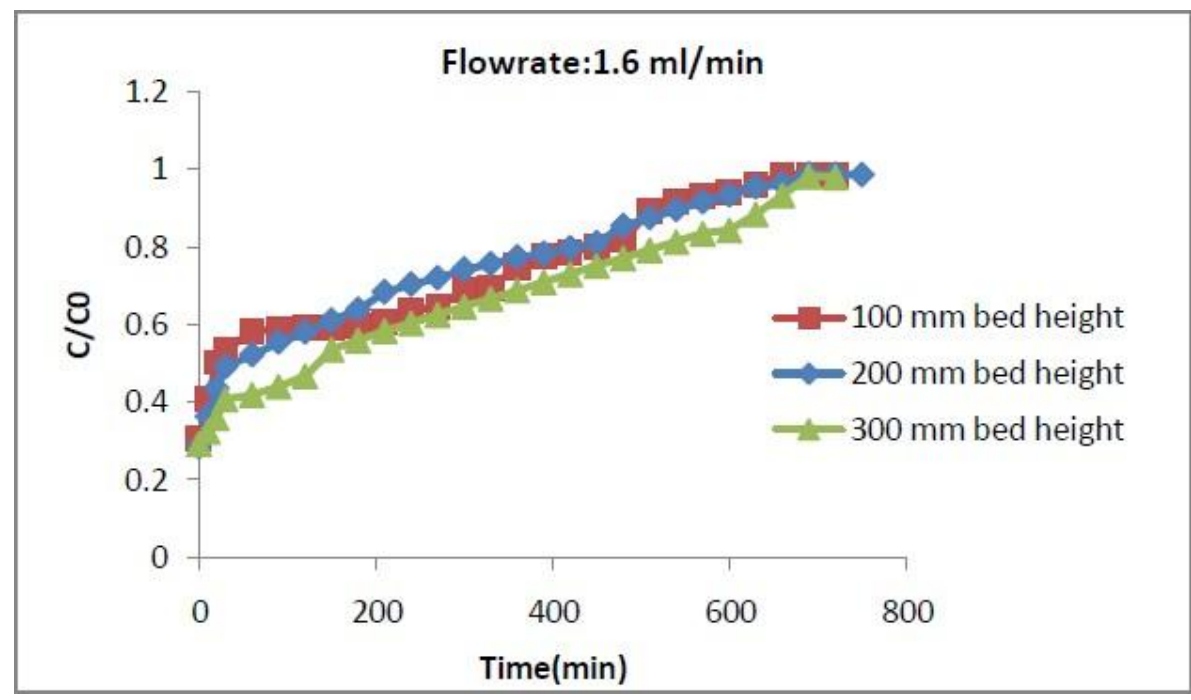

Fig.3.3.1. Effect of Bed Height on Break through Curve (Flow rate: $1.6 \mathrm{ml} / \mathrm{min}$ ) 


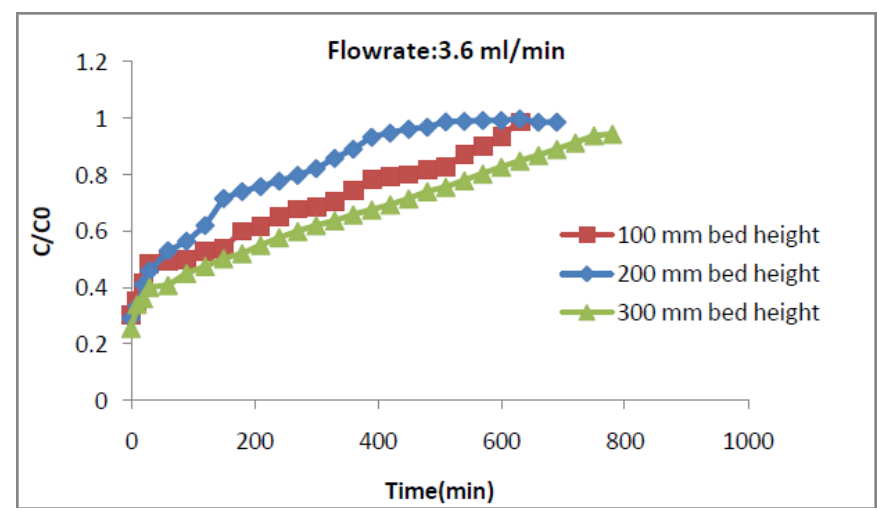

Fig.3.3.2. Effect of Bed Height on Break through Curve (Flowrate: $3.6 \mathrm{ml} / \mathrm{min}$ )

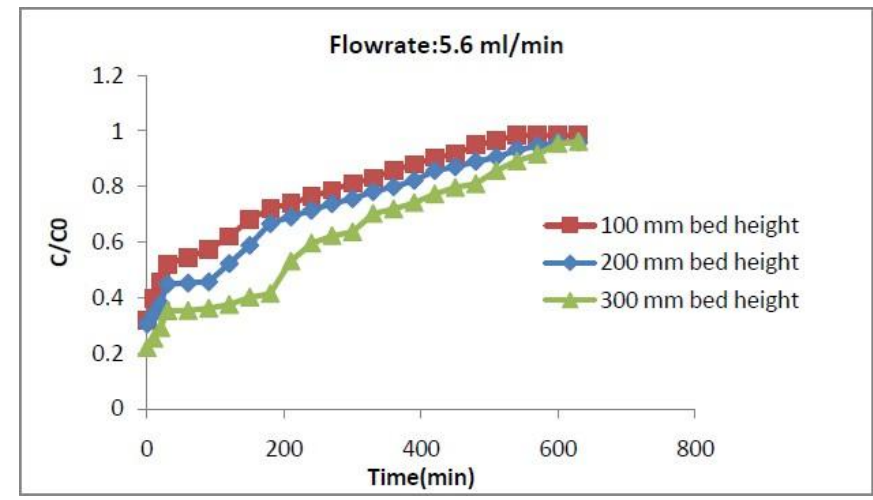

Fig.3.3.3. Effect of Bed Height on Break through Curve (Flow rate: $5.6 \mathrm{ml} / \mathrm{min}$ )

\subsection{Effect of Feed Concentration}

Adsorption experiments were carried out for the effect of adsorbate concentration on the column performance was studied by varying the feed concentration. . The experiments was carried out at three different bed heights namely $100 \mathrm{~mm}, 200 \mathrm{~mm}, 300 \mathrm{~mm}$ keeping other parameters like concentration of feed and feed flow rate constant. Adsorption experiments were carried out for the effect of adsorbate concentration such as $334.5 \mathrm{ppm}, 167.25 \mathrm{ppm}$ and $86.625 \mathrm{ppm}$ respectively on the column performance at optimum bed height and feed flow. Sulphur removal for optimum bed height $300 \mathrm{~mm}$ with feed flowrate $3.6 \mathrm{ml} / \mathrm{min}$ for varried conc. $334.5 \mathrm{ppm}, 167.25 \mathrm{ppm}$ and $86.625 \mathrm{ppm}$ was found to be $60.83 \%, 59.94 \%$, and $68.83 \%$ respectively.

The effect of initial sulphur concentration reduces with increase in the initial concentration. And the exhaustion time increased with decrease in initial concentration. Effect of sulphur concentration in feed solution on performance of breakthrough curves at optimum adsorbent bed height and flow rate is shown in fig 3.4.1. In the adsorption of sulphur a change in initial sulphur concentration affects the operating characteristics of the fixed bed adsorption column.It was observed that the adsorbent get saturated faster at higher concentrations of adsorbate due to the higher rate of adsorbent exhaustion at higher sulphur concentration. The exhaustion time for sulphur conc. $334.5 \mathrm{ppm}, 167.25 \mathrm{ppm}$ and $86.625 \mathrm{ppm}$ was $570 \mathrm{~min}, 570 \mathrm{~min}$ and $510 \mathrm{~min}$. respectively.

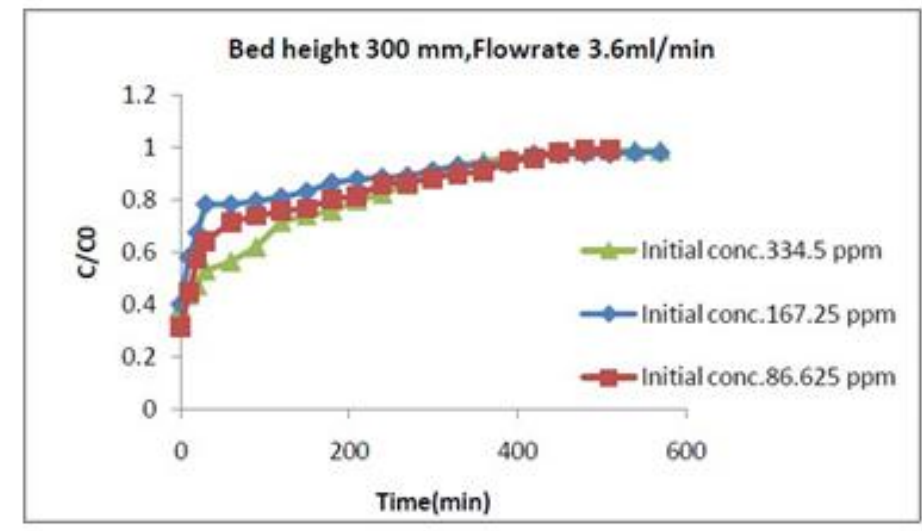

Fig.3.4.1. Effect of Initial Concentration on Break through Curve 


\subsection{Regeneration of Activated Carbon}

The regenerability of the spent adsorbent was conducted to assess its feasibility. For the improvement of life of activated carbon, regeneration of coconut shell activated carbon was carried out. Regenerability of the best performing sorbent, coconut shell activated carbon was studied to determine its feasibility for industrial applications. The regenerability consisted of solvent wash, ultrasonic treatment and heat treatment to test the regenerability of the spent sorbents. After regeneration, the adsorbent can be reused in the packed bed to absorb sulphur. Regeneration of coconut shell activated carbon was carried out by air drying and thermal treatment at high temp 800 ${ }^{0} \mathrm{c}$. The performance of the regenerated sorbent bed is similar to that of the fresh adsorbent bed indicating the usefulness of the developed regeneration process. Fig.3.5.1. shows the removal of sulphur by using regenerated of activated carbon. The regenerability of adsorbent was checked by carrying out new adsorption cycle at optimum bed height and flow rate. It was determined that by decreasing the feed flow and increasing bed depth, the values of output sulphur concentration were decreased and the breakthrough time was extended. The results showed that the regenerated adsorbent could recovered upto $49.17 \%$.

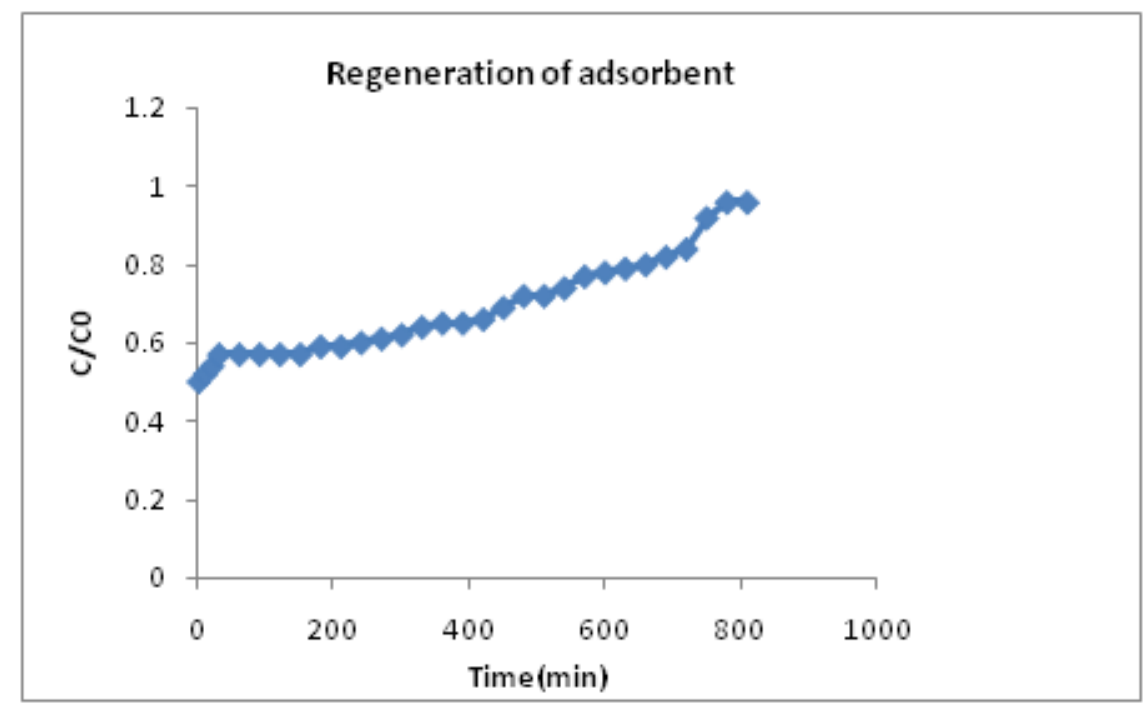

Fig.3.5.1.Sulphur removal by using regenerated activated carbon

\section{Modeling For PACKed Bed SulPhur Removal}

Theoritical breakthrough curves were tested using different models with corresponding experimental values. Different experimental run were carried out for various bed height, flow rate and concentration. In the present work effect of various parameters on applicability of Thomas and Yoon Nelson model and Adams-Bohart model for packed column data is studied Fixed bed experiments were carried out for removal of sulphur using coconut shell activated carbon. The performance of fixed bed in the form of breakthrough curves were obtained and tested using different kinetic models like Thomas, Adam-Bohart, Yoon-Nelson .Adsorption capacity $(\mathrm{mg} / \mathrm{g})$ was found from the models. The constants obtained from the models can be utilized for designing the industrial scale fixed bed.

The best fit model which fitted the experimental condition were determined by the computed $\mathrm{R}^{2}$ value.

\subsection{Effect of Flow Rate}

The experimental data for flow rate $1.6 \mathrm{ml} / \mathrm{min}$ to $5.6 \mathrm{ml} / \mathrm{min}$ was tested by all three models. It was observed that the data was well described by Thomas, Yoon Nelson model and Adams-Bohart model models. for all values of flow rate except flowrate $1.6 \mathrm{ml} / \mathrm{min}$. Yoon Nelson model for different flow rate is represented in fig. no.4.1.1,fig no.4.1.2.and fig no.4.1.3.for varried bed height The values of $\mathrm{R}^{2}$ of Yoon Nelson model for different flowrate $1.6 \mathrm{ml} / \mathrm{min}, 3.6 \mathrm{ml} / \mathrm{min}$.and $5.6 \mathrm{ml} / \mathrm{min}$ for bed height $200 \mathrm{~mm}$ were greater 0.9. which fits better than other two flowrates. Value of $\tau$ decreases with flowrate for all three bed heights. 


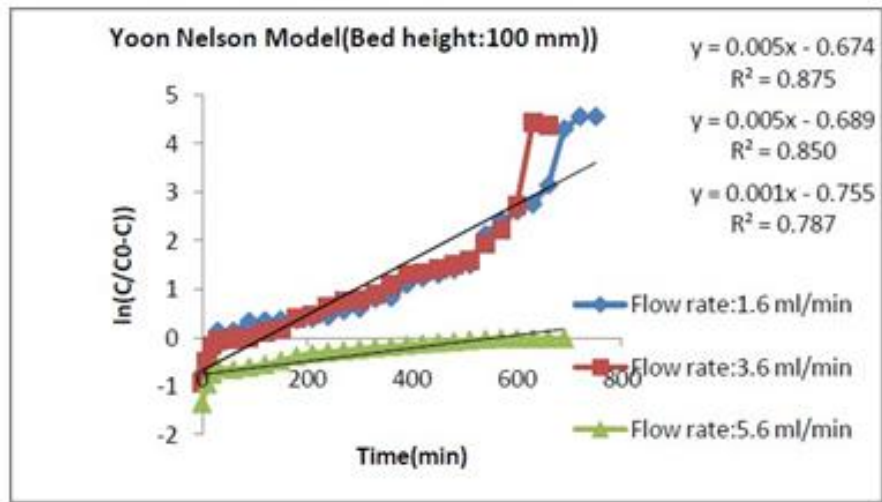

Fig.4.1.1: Yoon Nelson Model for Different Feed Flow Rate(100 mm bed height)

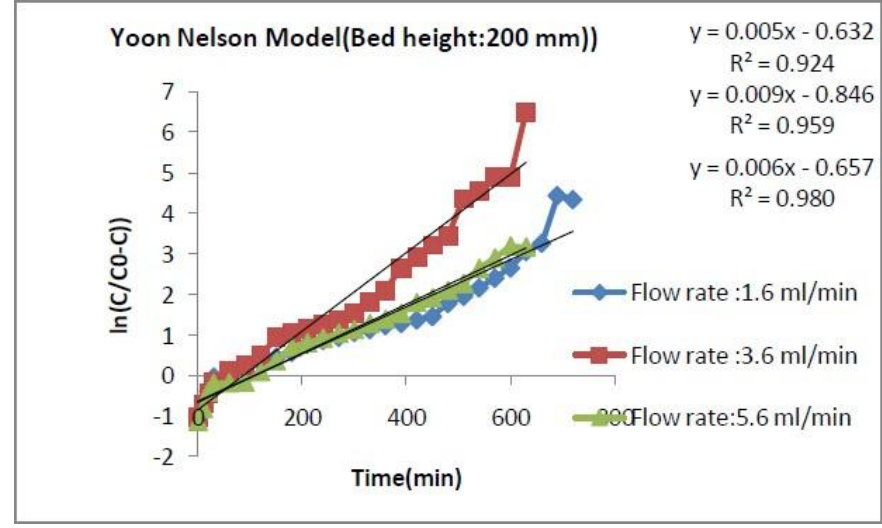

Fig.4.1.2: Yoon Nelson Model for Different Feed Flow Rate (200 mm bed height)

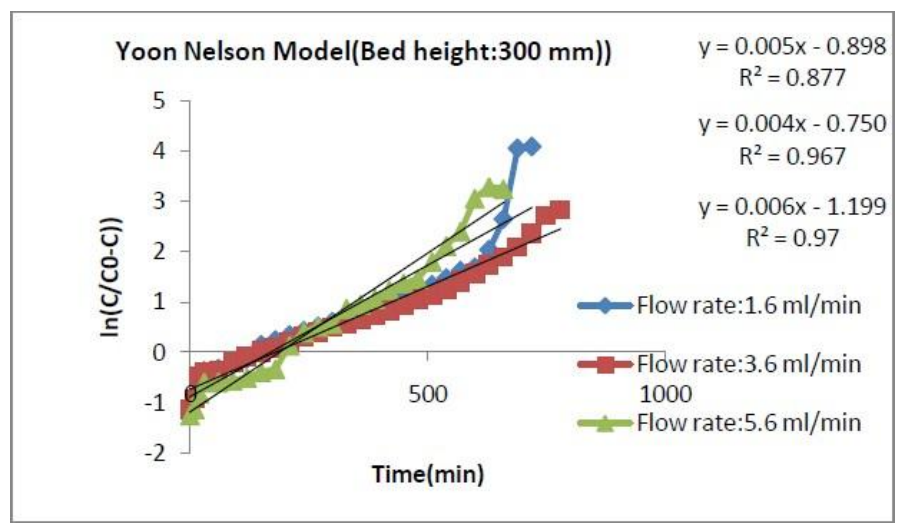

Fig.4.1.3: Yoon Nelson Model for Different Feed Flow Rate (300 $\mathrm{mm}$ bed height)

Thomas model gives better values of R2for all three flow rates for $200 \mathrm{~mm}$ bed height was shown in fig no.4.1.4,fig no.4.1.5 and fig no.4.1.6. For bed height $200 \mathrm{~mm}$ values of $\mathrm{R}^{2}$ of the Thomas Model were greater 0.9. which fits better than other two bed height for all three flowrates values of adsorption capacity q0 and constant $\mathrm{KT}$, increases with flow rates.

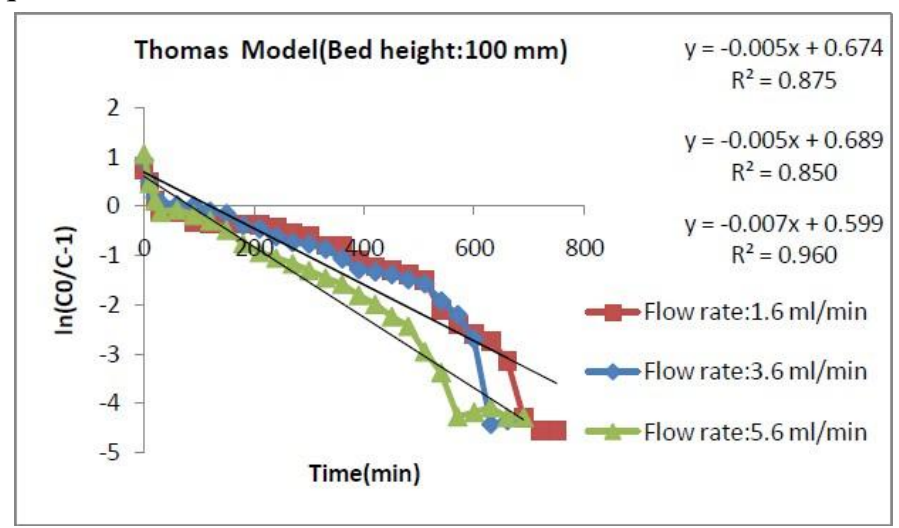

Fig.4.1.4: Thomas Model for Different Feed Flow Rate(100 mm bed height) 


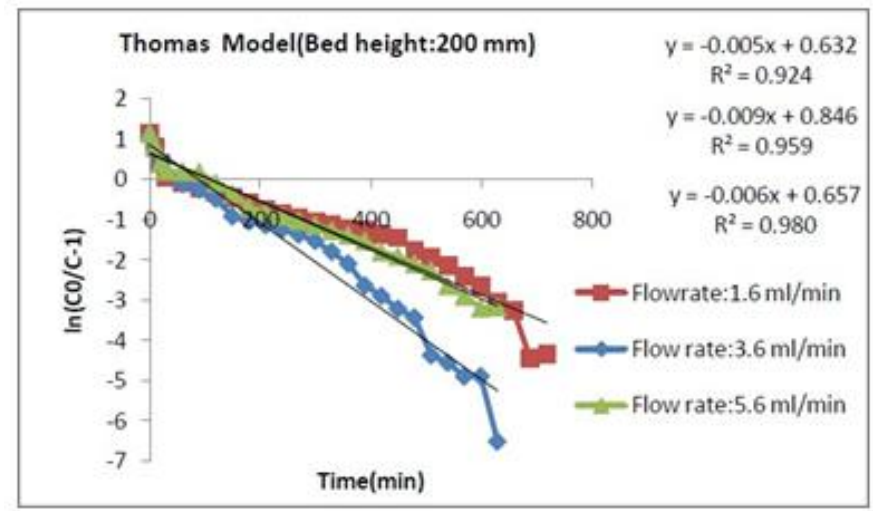

Fig.4.1.5: Thomas Model for Different Feed Flow Rate(200 $\mathrm{mm}$ bed height)

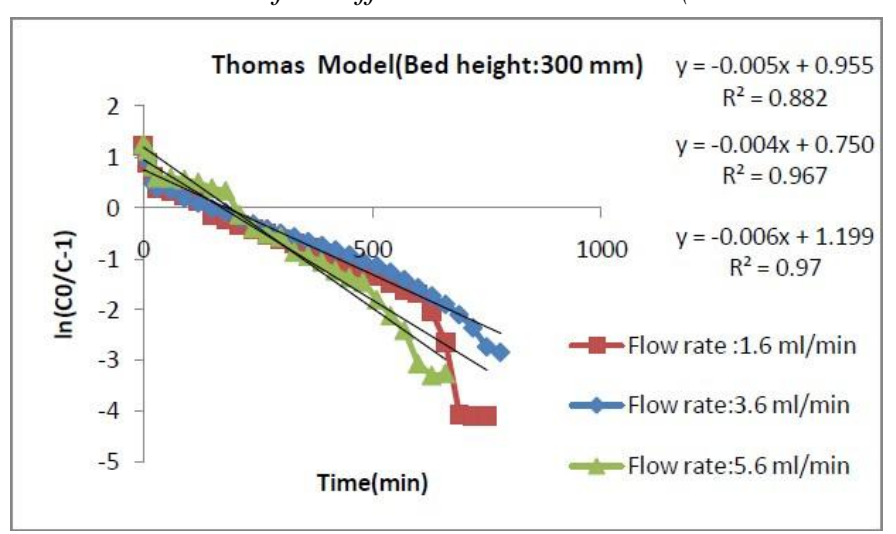

Fig.4.1.6: Thomas Model for Different Feed Flow Rate (300 $\mathrm{mm}$ bed height)

Adam Bohart model is shown in fig no. 4.1.7,fig no.4.1.8and fig no.4.1.9.Adam Bohart model gives satisfactory fit for all three flow rates with different heights with value of R2 near to 0.9. Value of N0 increases with flowrate and value of constant KAB is constant for bed height $200 \mathrm{~mm}$ and $300 \mathrm{~mm}$.

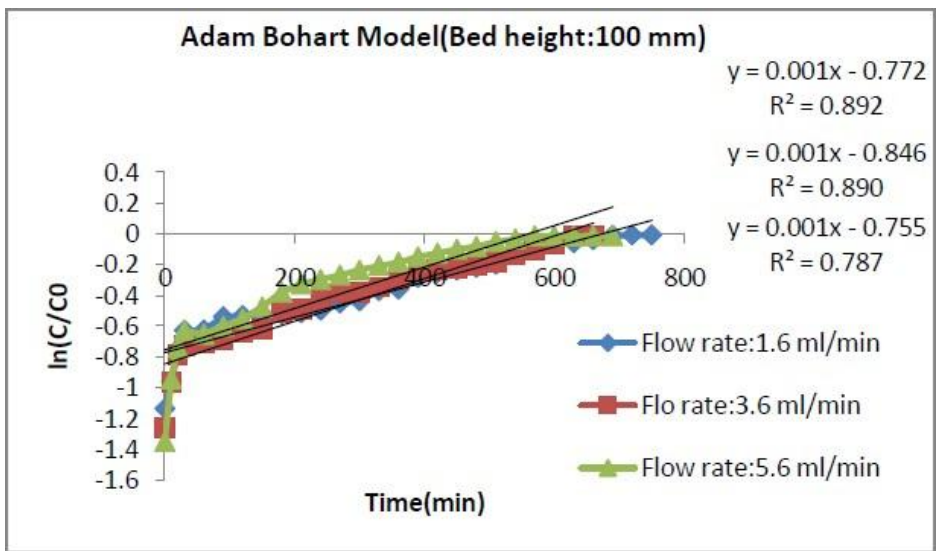

Fig.4.1.7: Adam Bohart Model for Different Feed (100 mm bed height)

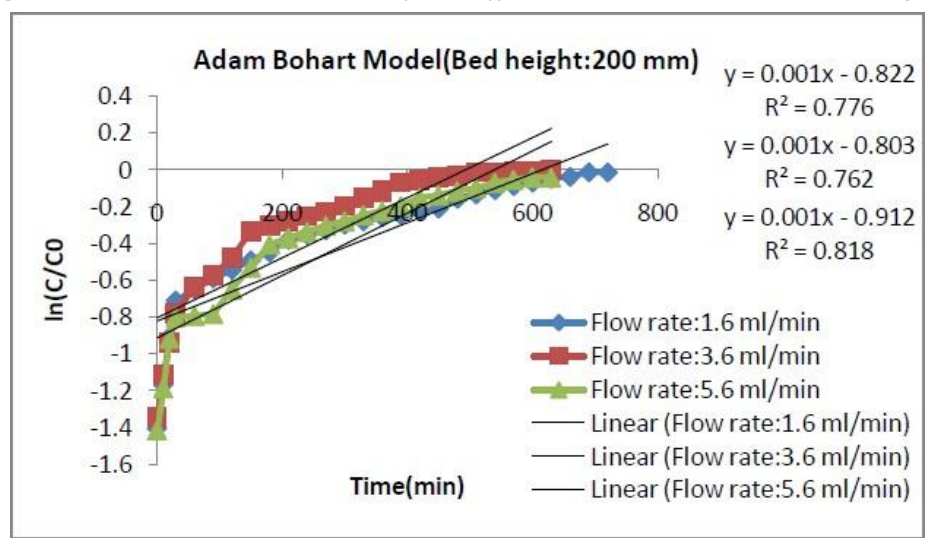

Fig.4.1.8: Adam Bohart Model for Different Feed Flow Rate(200 $\mathrm{mm}$ bed height) 


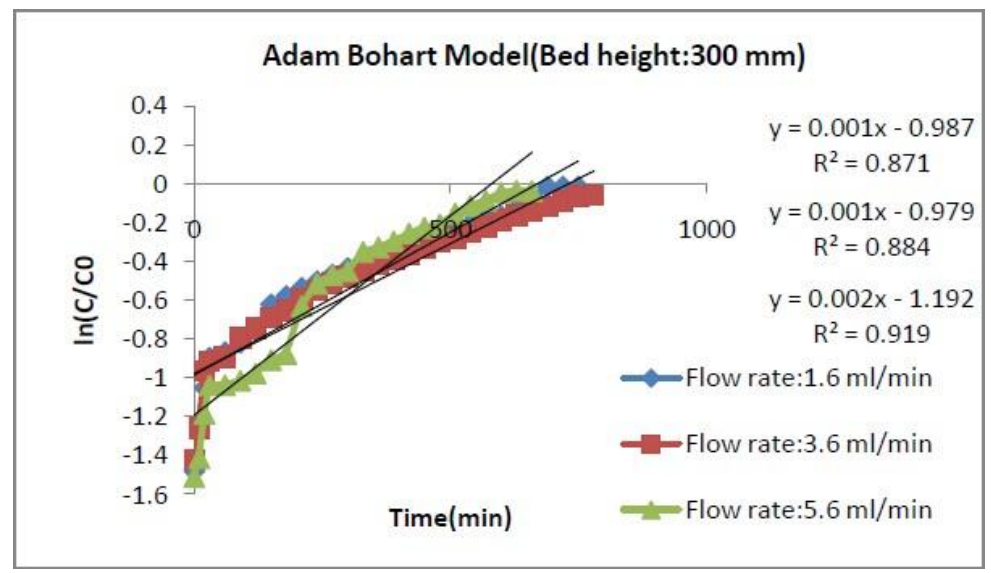

Fig.4.1.9: Adam Bohart Model for Different Feed Flow Rate(300 $\mathrm{mm}$ bed height)

\subsection{Effect of Bed Height}

It was observed that the data was well described by these three models The experimental data for bed height $100 \mathrm{~mm}$ to $300 \mathrm{~mm}$ was tested by all three models. It was observed that the data was well described by Thomas, Yoon Nelson model and Adams-Bohart model models. It can be concluded that Adams Bohart model provided best fit with value of $\mathrm{R}^{2}$ greater than 0.94

Effect of bed height on Yoon model parameters is shown in fig no. 4.2.1fig no.4.2.2 and fig no.4.2.3. Yoon Nelson model gives better result for all bed height for flow rate $5.6 \mathrm{ml} / \mathrm{min}$. with greater value of $\mathrm{R}^{2}$ for different bed heights than flowrate $3.6 \mathrm{ml} / \mathrm{min}$ and $1.6 \mathrm{ml} / \mathrm{min}$. Yoon Nelson time constant decreased with bed height up to $200 \mathrm{~mm}$.and for $300 \mathrm{~mm}$ it increases for all three flow rates $16 \mathrm{ml} / \mathrm{min}, 3.6 \mathrm{ml} / \mathrm{min}$ and $5.6 \mathrm{ml} / \mathrm{min}$.

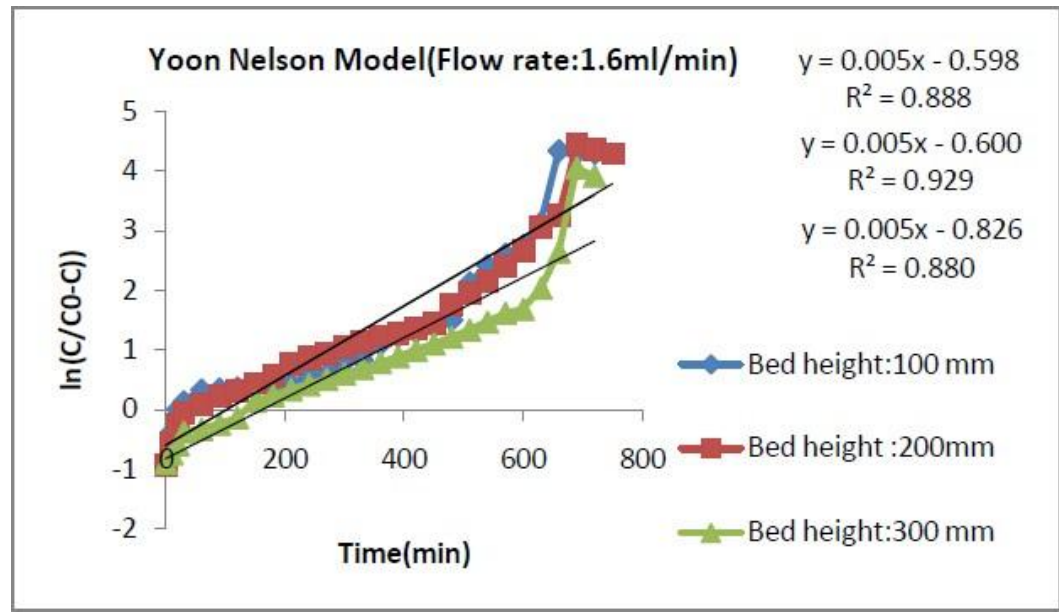

Fig.4.2.1. Yoon Nelson Model for Different Bed Height ( $1.6 \mathrm{ml} / \mathrm{min}$ flow rate)

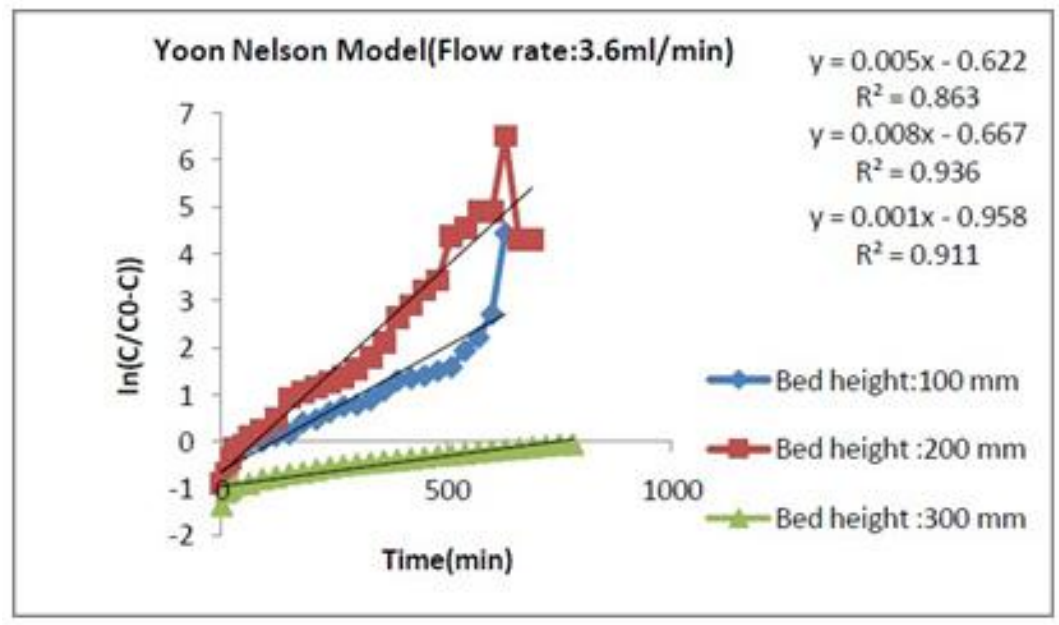

Fig.4.2.2. Yoon Nelson Model for Different Bed Height (3.6 ml/min flow rate) 


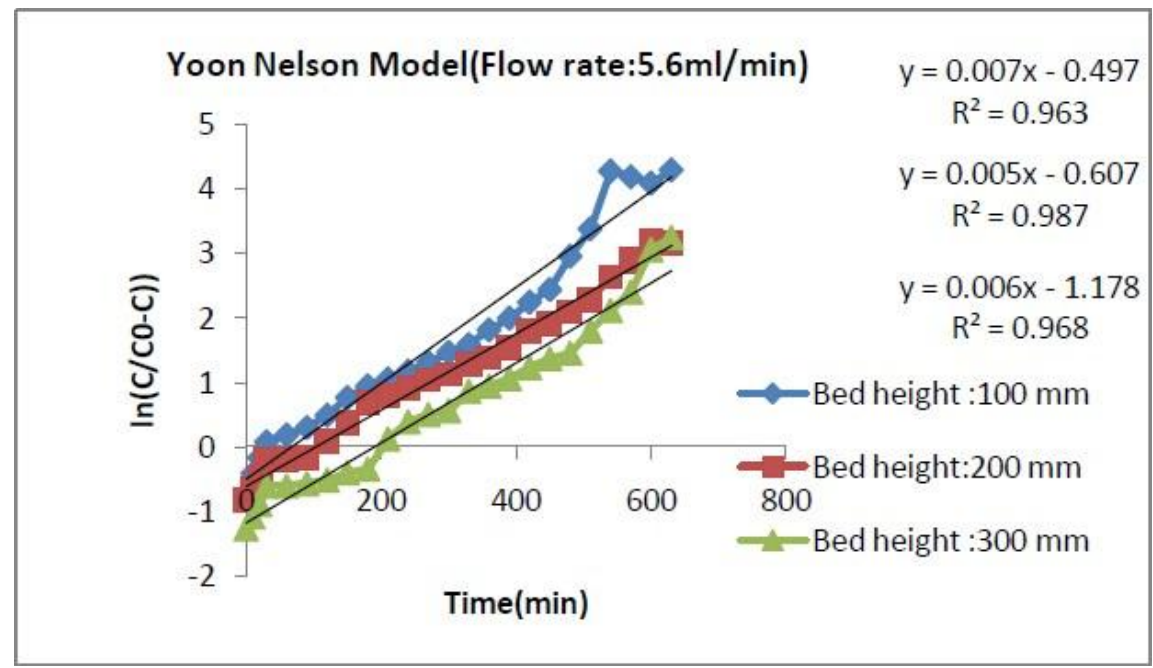

Fig.4.2.3.Yoon Nelson Model for Different Bed Height (5.6 ml/min flow rate)

Thomas model gives better results with greater value of $\mathrm{R}^{2}$ at flowrate $5.6 \mathrm{ml} / \mathrm{min}$ for all three bed height. Thomas model for different bed height is represented in fig. no.4.2.4,fig no.4.2.5 and fig no.4.2.6.for varried flowrate .Thomas parameter, $\mathrm{K}_{\mathrm{t}}$ increased with bed height for flow rate 3.6 $\mathrm{ml} / \mathrm{min}$ and initial concentration334.5. and it decreases for flowrate $5.6 \mathrm{ml} / \mathrm{min}$. while $\mathrm{q}_{0}$ adsorption capacity decreased with bed height for flowrate $1.6 \mathrm{ml} / \mathrm{min}$.

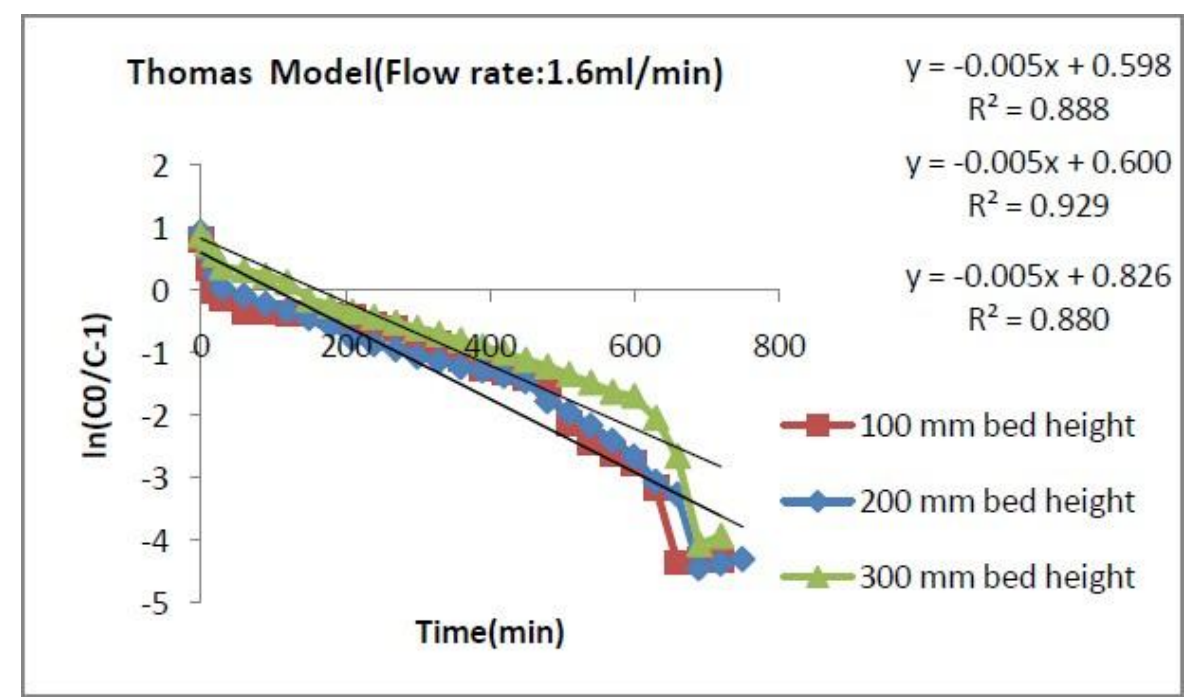

Fig.4.2.4: Thomas Model for Different Bed Height (1.6 $\mathrm{ml} / \mathrm{min}$ flow rate)

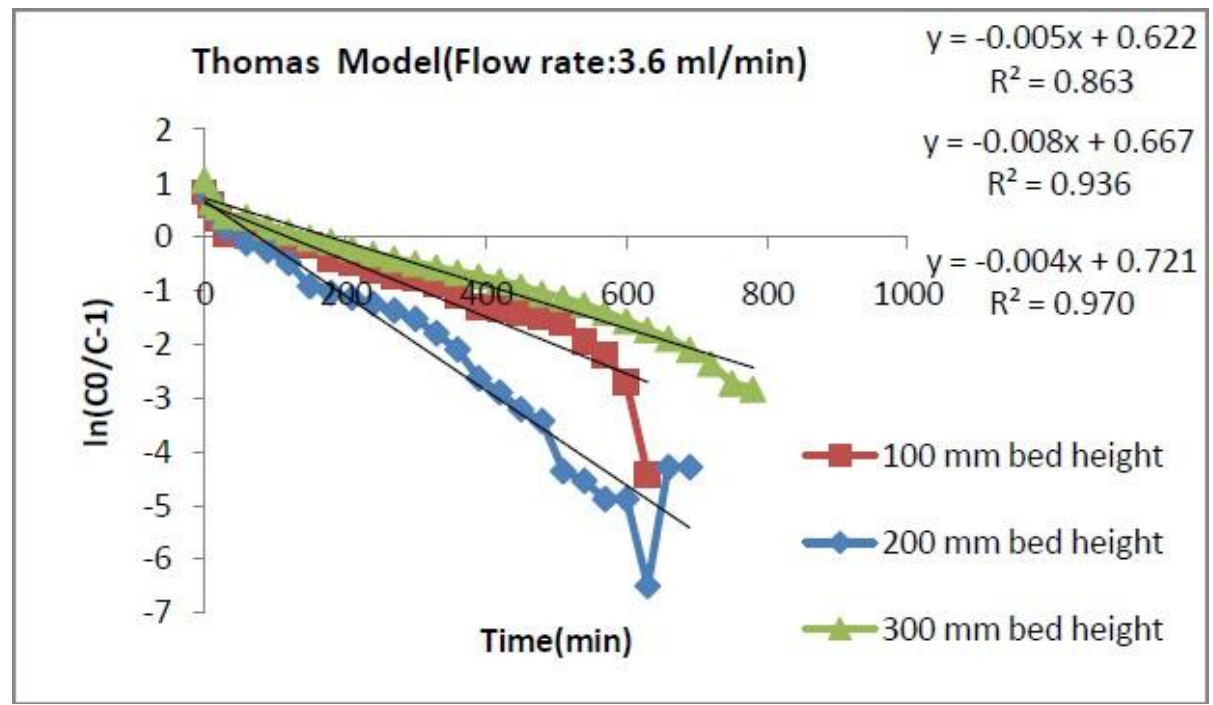

Fig.4.2.5: Thomas Model for Different Bed Height (3.6 $\mathrm{ml} / \mathrm{min}$ flow rate) 


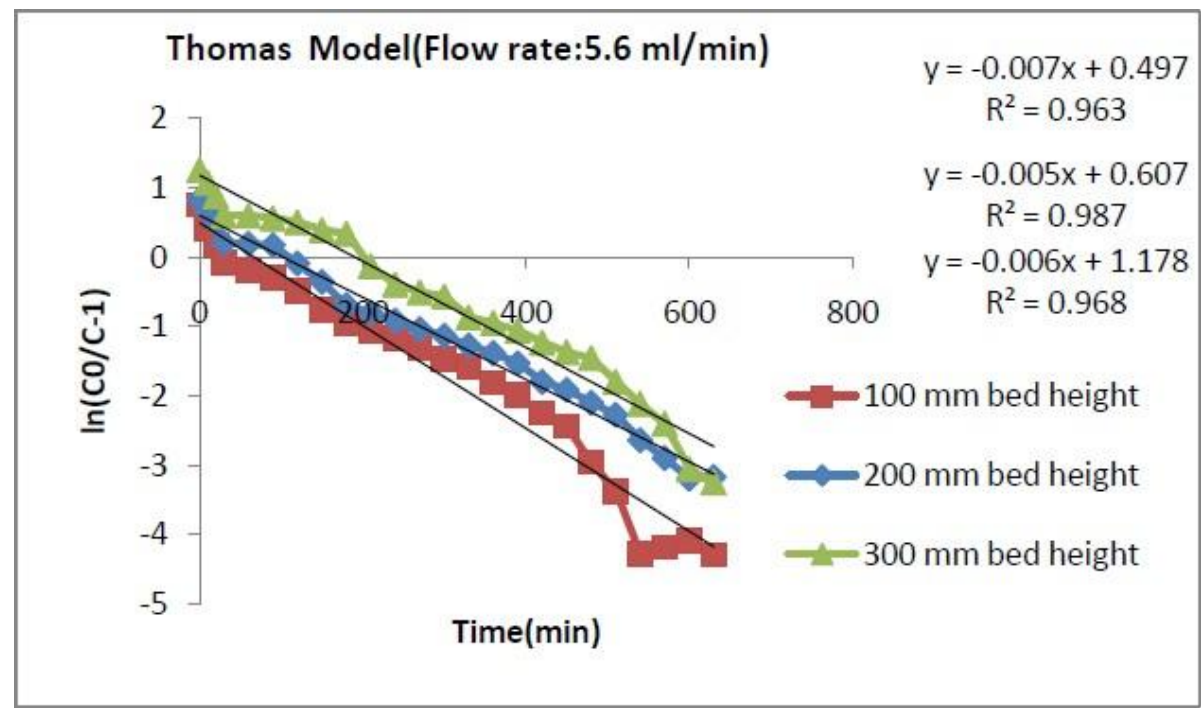

Fig.4.2.6: Thomas Model for Different Bed Height ( $5.6 \mathrm{ml} / \mathrm{min}$ flow rate)

Adams Bohart model models gives better results at flow rate $1.6 \mathrm{ml} / \mathrm{min}$ with greater value of $\mathrm{R}^{2}$ for bed height $100 \mathrm{~mm}, 200 \mathrm{~mm}$ and $300 \mathrm{~mm}$ with initial sulphur concentrations $334.5 \mathrm{ppm}$ as shown in fig no. 4.2.7, fig no.4.2.8 and fig no.4.2.9. Adam Bohart model, $\mathrm{N}_{0}$ increased with bed height Adam Bohart model gives poor result for bed height $200 \mathrm{~mm}$ and $300 \mathrm{~mm}$ at flow rate $5.6 \mathrm{ml} / \mathrm{min}$.

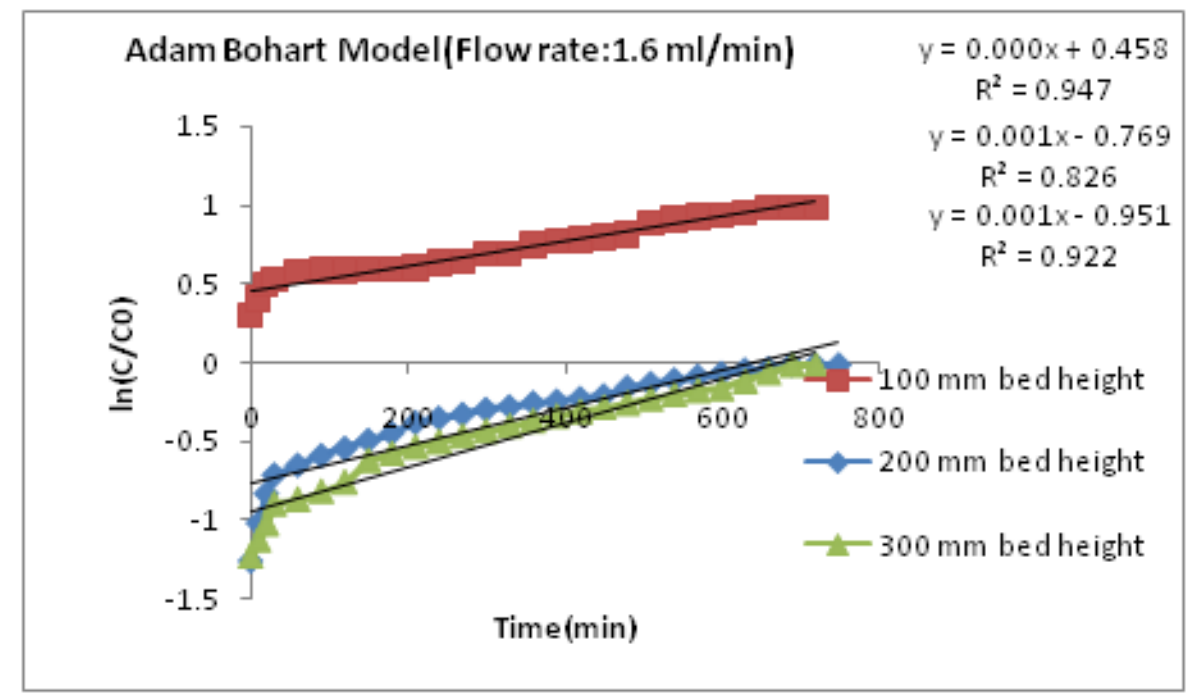

Fig.4.2.7: Adam Bohart for Different Bed Height(1.6 $\mathrm{ml} / \mathrm{min}$ flow rate)

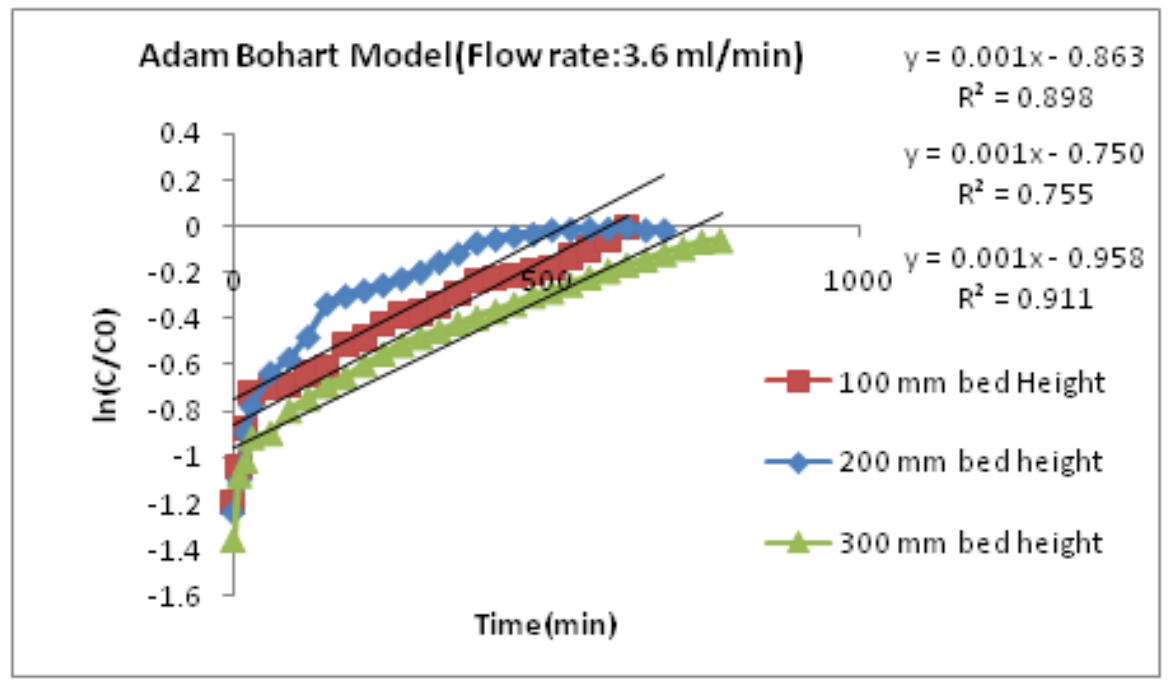

Fig.4.2.8: Adam Bohart for Different Bed Height (3.6ml/min flow rate) 


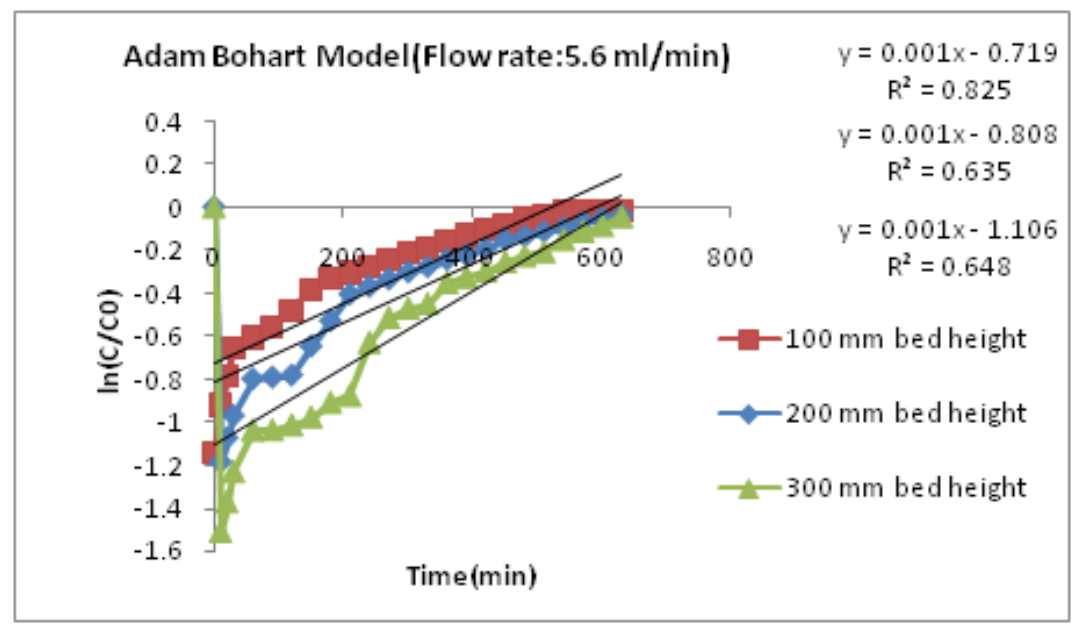

Fig.4.2.9: Adam Bohart for Different Bed Height (5.6 $\mathrm{ml} / \mathrm{min}$ flow rate)

\subsection{Effect of Initial Concentration}

It was observed that for Feed conc. 334.5 to 86.625 at optimum values of bed height and flow rate, Adam Bohart and Yoon Nelson model gives satisfactory results. Yoon Nelson model for different initial concentrations is represented in fig 4.3.1.The values of $\mathrm{R}^{2}$ of Yoon Nelson model for sulphur concentrations $334.5 \mathrm{ppm} .167 .25 \mathrm{ppm}$ and 86.625 were $0.98,0.64$ and 0.68 respectively.

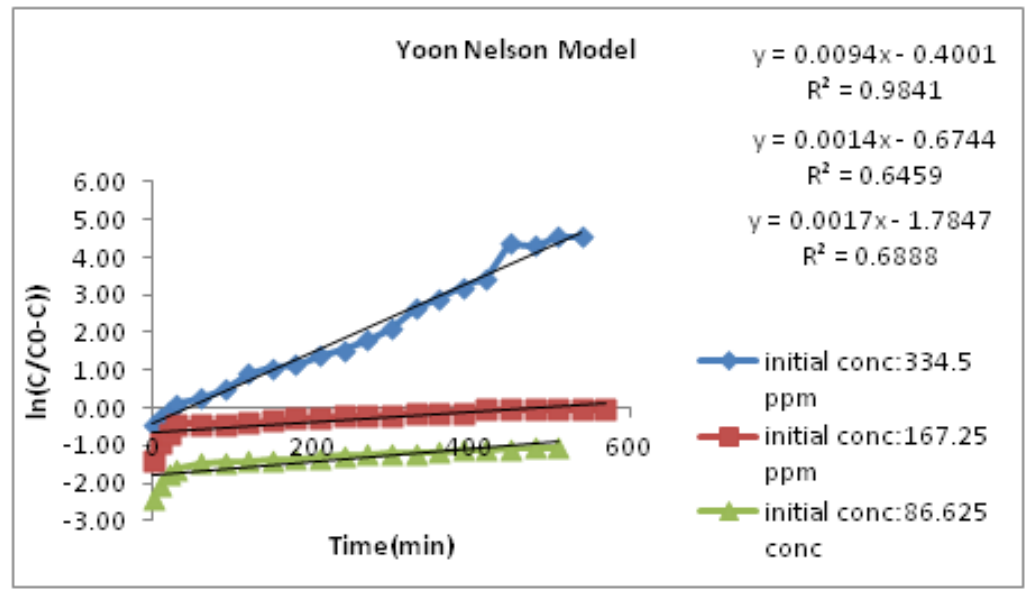

Fig.4.3.1: Yoon Nelson Model at Different Initial Concentrations

Thomas model is represented by fig no 6.3.2 fits the data for all initial concentration $334.5 \mathrm{ppm}$ to $86.625 \mathrm{ppm}$. with value of $\mathrm{R}^{2}$ greater than 0.9 . Thomas model for different initial concentrations is represented in fig.4.3.2.Thomas parameter, $\mathrm{K}_{\mathrm{t}}$ increased with initial concentration while $\mathrm{q}_{\mathrm{o}}$, adsorption capacity decreased with initial concentration. With initial concentration Thomas constant decreased. The time required for 50 percent breakthrough $(\tau)$ decreased with initial concentration.

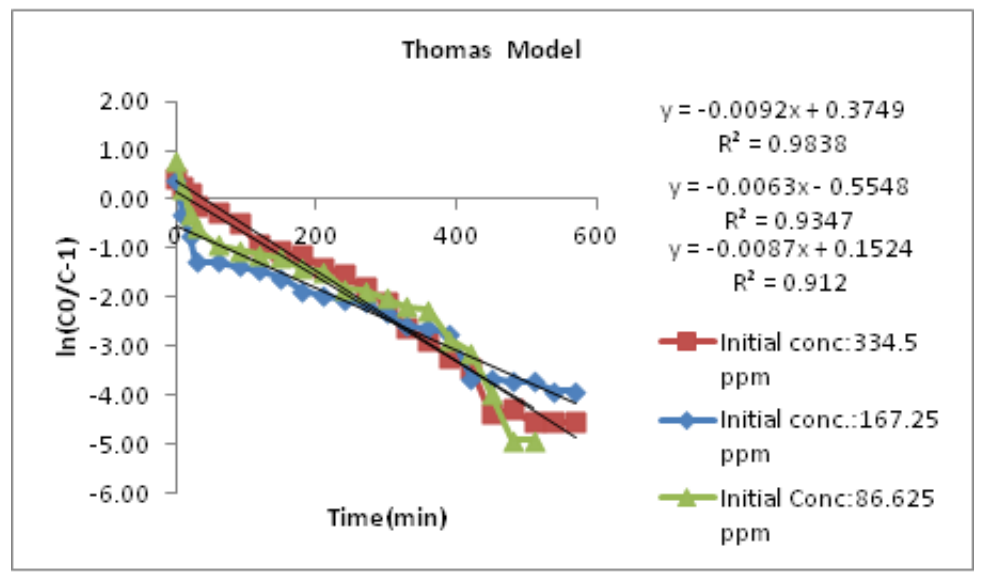

Fig.4.3.2: Thomas Model at Different Initial Concentrations 
Adam Bohart model gives poor result for the effect of initial concentration with value of $\mathrm{R}^{2}$ less than 0.9. In case Adam Bohart model, $\mathrm{NO}$ increased and KAB decreased with initial sulphur Concentration shown in fig no 4.3.3.

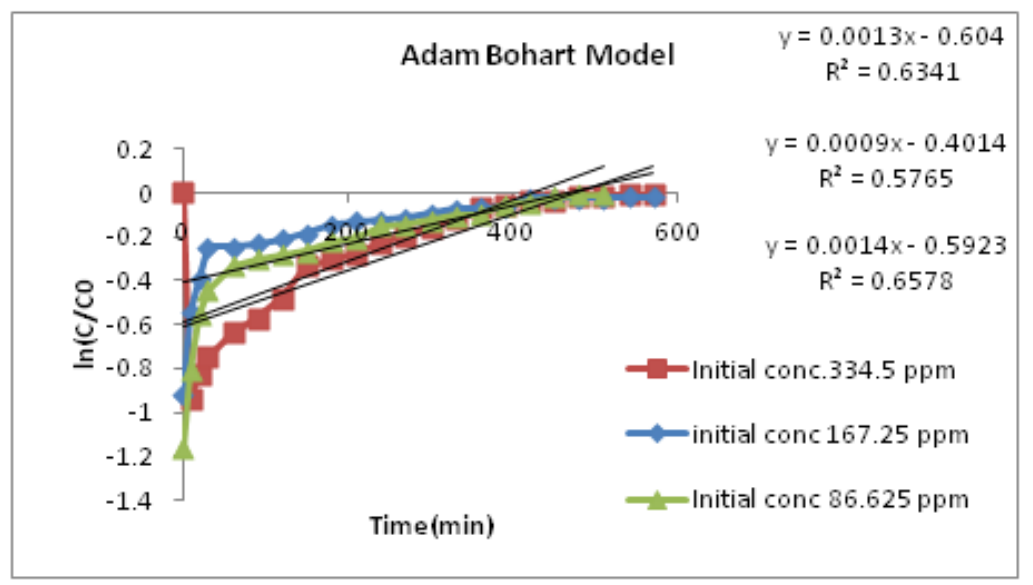

Fig.4.3.3. Adam Bohart Model at Different Initial Concentrations

Yoon \& Nelson, model, Thomas model and Adam Bohart model parameters were estimated from experimental data.It was observed that the parameters like initial concentration, flow rate, bed height affect the model parameters significantly.

\section{CONCLUSION}

Fixed bed adsorption experiments were carried out at different feed flow rates, bed heights and feed concentration. It was found that all flowrates $1.6 \mathrm{ml} / \mathrm{min}$ the exhaustion time was 720,750 and 720 minutes for bed height $100 \mathrm{~mm} 200 \mathrm{~mm}$ and $300 \mathrm{~mm}$ respectively. At flowrate $3.6 \mathrm{ml} / \mathrm{min}$ for bed height $100 \mathrm{~mm} 200 \mathrm{~mm}$ and $300 \mathrm{~mm}$, exhaustion time was $540 \mathrm{~min} 570 \mathrm{~min}$ respectively. The exhaustion time was 720 min The increase in bed height leads to decrease in the output sulfur concentration. $200 \mathrm{~mm}$ bed height gives better results for flow rate $5.6 \mathrm{ml} / \mathrm{min}$ with sulphur removal 77.93\%.Maximum sulphur removal for $200 \mathrm{~mm}$ and $300 \mathrm{~mm}$ bed was found $74.11 \%$ and $75.68 \%$ respectively for flow rate $5.6 \mathrm{ml} / \mathrm{min}$. It was observed that the adsorbent get saturated faster at higher concentrations of adsorbate due to the higher rate of adsorbent exhaustion at higher sulphur concentration. The exhaustion time for sulphur conc. $334.5 \mathrm{ppm}, 167.25 \mathrm{ppm}$ and $86.625 \mathrm{ppm}$ was 570 $\mathrm{min}, 570 \mathrm{~min}$ and $510 \mathrm{~min}$. respectively.Adsorption experiments were carried out using regenerated activated carbon The results showed that the regenerated adsorbent could recovered upto $49.17 \%$.

\section{REFERENCES}

[1] Dat T. Tran, Zachary W. Dunbar, and Deryn Chu, "Adsorptive Desulfurization of JP-8 Fuel Using Ag+/Silica Based Adsorbents at Room Temperature",Army Research Laboratory,pp.1-22,Sept 2012.

[2] Penelop Baltzopoulou, Kyriakos X. Kallis, George Karagiannakis, Athanasios G. Konstandopoulos "Diesel Fuel Desulfurization via Adsorption with the Aid of Activated Carbon Laboratory- and Pilot-Scale Studies ”, American Chemical Society, Energyfuels.5b01133 Energy Fuels, 29, PP.5640-5648, 2015.

[3] Alain Favre-Reguillon,Marc Sevignon, Muriel Rocault,Emmanuelle Schulz,Marc Lemaire,"Deep Desulfurization of Diesel Feedstock by Selective Adsorption of Refractory Sulfur Compounds ”,Eng. Chem. Res47,pp 9617-9622, 2008

[4] Huang Tanga,Wangliang Li ,Ting Zhanga,Qiang Li Jianmin Xinga, Huizhou Liua,"Improvement in diesel desulfurization capacity by equilibrium isotherms analysis", Separation and Purification Technology 78,pp. 352-356,2011.

[5] Weiwei Li, Jingwen Chen, Guojing Cong, Lei Tang, Qun Cui, Haiyan Wang, "Solvent desulfurization regeneration process and analysis of activated carbon for low-sulfur real diesel ", Royal Society of Chemistry, pp. $20258-20268,2016$

[6] Mykola Seredych, Jakub Lison, Urs Jans, Teresa J. Bandosz, “ Textural and chemical factors affecting adsorption capacity of activated carbon in highly efficient desulfurization of diesel fuel ", Carbon 47,pp. 2491-2500,2009

[7] Vinay M. Bhandari1, Chang Hyun Ko, Jung Geun Park, Sang-Sup Han, Soon-Haeng Cho, Jong-Nam Ki“ Desulfurization of diesel using ion-exchanged zeolites ",Chemical Engineering Science 61,pp. 2599 2608,2006 
[8] Jie Bu, Gabriel Loh, Chuandayani Gunawan Gwie, Silvia Dewiyanti, Michael Tasrif, Armando Borgna, "Desulfurization of diesel fuels by selective adsorption on activated carbons:Competitive adsorption of polycyclic aromatic sulfur heterocycles and polycyclicaromatic hydrocarbons ", Chemical Engineering Journal 166 ,pp 207-217, 2011.

[9] Soumen Dasgupta , Pushpa Gupta , Aarti , Anshu Nanoti , Amar N. Goswami a, Madhukar O. Garg , Elisabeth Tangsta, Ornulv . Vista , Arne Karlsson , Michael Stocker , "Adsorptive desulfurization of diesel by regenerable nickel based adsorbents ”, Fuel 108 ,pp184-189, 2013.

[10] Anne Kerolaine O. Rodrigues , Josy Eliziane T. Ramos , Celio L. Cavalcante , Enrique RodríguezCastellon, Diana C.S. Azevedo "Pd-loaded mesoporous silica as a robust adsorbent in adsorption/ desorption desulfurization cycles ", Fuel 126,pp. 96-103,2014

[11] Marko Muzic, Zoran Gomzi, Katica Sertic Bionda“Analysis of continuous fixed bed adsorptive desulfurization of diesel fuel".

[12] Marko Muzic, Katica Sertic-Bionda, Zoran Gomzi,"Kinetic and Statistical Studies of Adsorptive Desulfurization of Diesel Fuel on Commercial Activated Carbons ",Chem. Eng. Technol., 31, No. 3, PP.355-364,2008.

[13] M. Muzic, K. Sertic-Bionda,T. Adzamic, "Desulfurization of Diesel Fuel in a Fixed Bed Adsorption Column: Experimental Study and Simulation ”, Petroleum Science and Technology, 29,PP.2361-2371, 2011.

[14] Arturo J. Hernandez Maldonado, Frances H. Yang, Desulfurization of transportation fuels by pcomplexation sorbents $\mathrm{Cu}(\mathrm{I})-, \mathrm{Ni}(\mathrm{II})$-, and $\mathrm{Zn}(\mathrm{II})$-zeolites, Gongshin Qi, Ralph T. Yang,Applied Catalysis B: Environmental 56,PP.111-126,2005.

\section{AUTHORS' BIOGRAPHY}

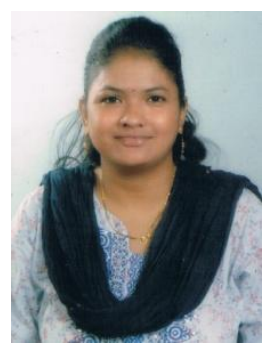

Mrs. Pratibha R. Gawande, has completed her Masters in Chemical Engineering and Membrane separation and technology.She is working as Assistant Professor in Chemical Engineering Department of Datta Meghe College Of Engineering, Navi Mumbai having 13 years teaching experience Her area of interest includes membrane separation and technology and Adsorption.

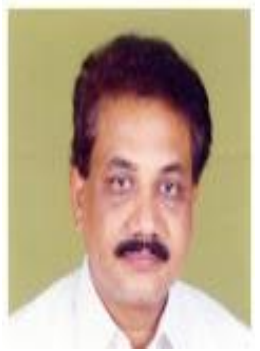

Dr. Jayant Prabhakarrao Kaware, male, Chemical Engineer, pursued his education from Laxminarayan Institute of Technology, Rashtra Sant Tukdoji Maharaj Nagpur University. He was working for Shri Shivaji Education Society's College of Engineering \& Technology since 1987. He was Professor-in-charge for the Biodiesel Research Laboratory associated with the department of chemical engineering. He was Member of Board of Studies for Chemical \& Polymer Technology at Sant Gadge Baba Amravati University since 2000 and Chairman from 2008 till 2012. He is a Member of Academic Council since 2005 in the University. He was a Member of Management Council of Sant Gadge Baba Amravati University till August, 2011. He is working in the various universities as Member of Research Recognition Committee, Board of University Teaching \& Research since 2006. He has published more than 36 research papers. He is working on various policy making government bodies related to biodiesel.

Citation: Pratibha R.Gawande \& Dr. Jayant P.Kaware, (2018). Fixed bed adsorption and modelling for desulphurization of diesel using coconut shell activated carbon, International Journal of Petroleum and Petrochemical Engineering (IJPPE), 4(2), pp.29-43, DOI: http://dx.doi.org/10.20431/2454-7980.0402005

Copyright: (0) 2018 Pratibha R.Gawande \& Dr.Jayant P.Kaware. This is an open-access article distributed under the terms of the Creative Commons Attribution License, which permits unrestricted use, distribution, and reproduction in any medium, provided the original author and source are credited 